\title{
ANALYSIS OF THE RATIONALITY CRIMINALIZATION BASED ON THE PHILOSOPHY TEACHINGS
}

\section{ANÁLISE DA CRIMINALIZAÇÃO DA RACIONALIDADE BASEADA NOS ENSINAMENTOS DA FILOSOFIA}

\section{Elnaz Bahramali ${ }^{1}$}

\begin{abstract}
Intellectual teachings has been introduced as one of the most important sources of influence on legislative policy of the past few centuries, so that under the influence of events in different places and times always was promoted the method and way of legislative policy, that have provided with reproducing elements in the social and human environment, components, and various variables for model making criminalization of behaviors. Patterns that since today have observed the impact on policy-making and criminalization of behaviors. In fact, on the basis of such a procedure which intellectual have been able to discover the different variables of mental and social and involved in the formation process of criminalization in the human history, and offer a procedural that sometimes become as a foundation and model for the legislature for many years, therefore, in this study by survey of these mental and social variables with philosophical approach has been tried, the hidden aspects is examined deeper and rational more accurate that less paid it on how in formation of behaviors criminalization, so as thereby to effects with and without mediated was honored on the criminalization of behaviors by the teachings of philosophical and rational.
\end{abstract}

Keywords: criminalization, rationalist, philosophical, legislative policy

\section{Resumo}

Ensinamentos intelectuais foram introduzidos como uma das mais importantes fontes de influência sobre a política legislativa dos últimos séculos, de modo que sob a influência de eventos em diferentes lugares e épocas sempre foi promovido o método e o caminho da política legislativa, que proporcionaram elementos, reproduzindo no ambiente social e humano,

\footnotetext{
${ }^{1}$ Phd student at Islamic Azad University. E-mail: kookakoolai@gmail.com
} 
componentes, e várias variáveis para o modelo que promove a criminalização de comportamentos. Padrões que desde hoje têm observado o impacto na formulação de políticas públicas e tipificação comportamentos. De fato, com base em tal procedimento, os intelectuais puderam descobrir as diferentes variáveis sociais e psíquicas e envolveram-se no processo de criminalização de alguns comportamentos na formação da história humana e ofereceram um procedimento que às vezes se tornou o fundamento e modelo de legislatura, por muitos anos, para a humanidade. Portanto, neste estudo, por meio do levantamento destas variáveis psíquicas e sociais com abordagem filosófica, os aspectos ocultos são examinados de forma mais racional e aprofundada, sendo mais precisos, desse modo, os efeitos com e sem mediação foram honrados na criminalização de comportamentos pelos ensinamentos filosóficos e racionais.

Palavras-chave: criminalização, racionalista, filosófica, política legislativa

\section{INTRODUCTION}

Every legal system is composed of elements that are shaping the system that this system requires a deep thinking attitude to criminalization of behaviors reproduction of these elements. Therefore, criminalization of behaviors process is not created in a vacuity but it takes shape in human and social environment, which is effective upon on it various factors and variables. One of these components is rational principles and philosophical doctrines. However, these teachings philosophical and rational put these effects with what quality, how and through what process something is that many aspects of it are unknown and neglected. Accordingly, what is interested in this research is how the process of rationalist criminalization, that whether directly or indirectly, can specify the framework and form the criminalization of behaviors. In fact the purpose author would be survey of tools, methods, theoretical and practical possibility to influence rational criminalization on criminalization of behavior. In other words, it seems that today the dominant paradigm in Iranian law is Pseudorational - Pseudonarrative paradigm: The Pseudorational also, in the sense that lawyers are always trying to invoke on Pseudorational basics, even though these principles are not rooted in reality ${ }^{2}$. Therefor it seems to naturally the process of criminalization of behavior will not be excluded from this process. For example, a

\footnotetext{
${ }^{2}$ Iranpur, Farhad, Rethinking on legal methodology and epistemology, Rokhdadeno publisher, 2013, p.44
} 
new topics in the current prevailing trends in criminal justice is the basis for legislation the efficiency of the experience of other countries and use testimonials and consequently in legal texts and translation into Persian language. In fact such an approach have seen needless his own of science particular experience in the areas of undetected or rather less attention the human sciences and rather down attention to analysis social and naive facts in the process of criminalization of behaviors, be adequate in the historical experience or other communities experience in different times and places, without their actual and potential capacity in tradition, culture, religion and ..... realized and consider in the form of philosophical doctrines. It might seem a bit hasty, but I must accept that if we want to solve problems in the process of criminalization of legislative that will not have a choice unless to think about more seriously about an element of consciousness and rational on the basis of philosophical views that have uncovered aspects of reality and the legislation and its principles have la place and la time aspects, and in the start time, determine invisible boundaries rationalist criminalization with the use philosophical teachings to the legislator.

Accordingly, the author believe that in the contents ahead primarily discusses on the position of these principles about the criminalization process, in the second step would determine the challenges ahead on the way to the criminalization of rationalist and would recognize its limits and borders and finally achieve to conclusion with regard to the rational and philosophical framework.

\section{THE POSITION OF RATIONAL PRINCIPLES IN CRIMINALIZATION PROCESS}

Criminal Codex is the effect of community life and superstructure, that the rational principles compose its foundation. In fact, rational and philosophical doctrines derived from the concept and meaning of human life that philosophers with use of its deal to process and analyze its philosophical foundations. On the other hand, criminalization is a component in the legislative process which can be influenced directly or indirectly by the teachings of rational teaching. Such that primarily rational principles expressed and extracted in the form of philosophical views and then when became recognize its borders has to find its components in legislative policy during the process of macro policy and determine the general format of criminalization for the legislator. Of course it appears type and form of criminalization process does not end only here. But also legislative policy are considered as affecting areas related to competition between interests and values and ideology, that usually due to the necessity of 
historical, social, and place demonstrate one of the components of the interests, values and ideologies or having to leads the compromise all of them in legislation. ${ }^{3}$

It should be said that the logic of this mechanism can be used with the principles and teachings as philosophical doctrines and the priority and epilogue principles of the criminalization process of behaviors has been recognized in policy making with these teachings and determine its borders. Of course compliance with this logic is not something that is talked today in the criminalization process of behaviors, or we want it to be designed. But can be observed such a mechanism in ancient times as a current practice, if in the idea of rights on that time was moral value for crime and consequently punishments for example. In fact, in previous time periods according to the prior and subsequent principles were measured the place and social needs to criminalize behavior.

For example, the Code of Hammurabi for the first time in those territory crimes such as murder, which until then were considered purely civil offenses and with pay financial as compensation to the victim or guardian has been criminalized, and was under the protection of criminal law ${ }^{4}$.

Unfortunately, despite such a history, a process that can be seen today in policy making is anything other than using of rational findings and philosophical perspectives basics for the temporal and spatial necessary surveys in criminalizing behavior. In other words, instead of the philosophical doctrines influential in basic selections on policy making, more has been effective on the form and content of the dialogue policy. In fact, it seems, the more instead observe the collective rationality in recognized the general trend of policy making more have been involved and witness in the excitement of this theory. On the other hand, the overall trend for the legislative policy for legislation and criminalization with the advent of modernity rules in life during 1930 and 1970, which more gradually emerged and developed, introduced new concepts in policies that criminalize new behaviors which it was less considered previously. In fact the new law on political support for the victim moves to the human rights ${ }^{5}$. In a form that in some cases extreme faced legislative process with new challenges and unexpected, and could be saying this trend also continued and or even in some special case has been get into sharper steep than with own past, and if couldn't defined the exact mechanisms for it, this subject

\footnotetext{
3 With a summary of, Farajiha, M, Aspects of affected criminology on criminal policy, Modares Law Journal, Volume 7, No. 1, Spring 2004, p. 116.

${ }^{4}$ Badamchi, Historical sociology of criminal law, Negahe Moaser Publishing, 2005, p. 14.

${ }^{5}$ With a summary, Marti, D. Huge systems of criminal policy, Translated by Ali Hossien Najafi Abrand Abadi, Mizan, Volume of 2, 2008, p.71
} 
expected that criminations trend to descent in today world would not be far of mind. Accordingly, it seems that today's more than past should need a mechanism that would be able to save policy process of this status and maybe couldn't imagine this mechanism without using of rational basics and philosophical principles.

In fact, today feel to need for philosophical teachings in criminalizing behaviors more than ever, this means could be defined more precise mechanism in the policies, and as a realistically filter assess efficiency in criminalizing policy today, and could be push heavy shadow of demagogy and common policies of modernization, and is established independent legislative policymaking process for the criminalization of behaviors.

Also principles and basics rational can be determined in many cases to the circle of our understanding of the crime. Because crime or with better worlds the definition of the crimination always faced with many challenges in disagreements between doctrine and theorists and with this reason couldn't was integrated on this issue. Even in some cases have been tried, which unit and same define provided that this attitude has also not been successful.

So it may be stated that the application of the rational and philosophical principles and basics can be specified to reach a consensus on the definition of the crime in here. In fact, it can be proven that is criminalize is something backward and is based on infrastructure science like philosophy ${ }^{6}$ that may be close it by the way. That is, a deep impression of legislative policy are depends on complete understanding of policymakers with approach and deep perspective philosophical that have always high influenced and contributed to the criminalization of behavior. . In other words, if familiar with the rational basics and philosophical teachings take precedence over legislative policy, at the time, that can became familiar with a source of failures and weaknesses legislative policies that involved in criminalize behaviors and fundamentally remove the problem and difficulties.

In fact, the use of rational principles in crime is not what that only humanity today wants to used it. Ancient Mesopotamia but also, have to be used more rational principles in the process of criminalization as applied. For example, they believed that the two phenomena are always following to each other, necessarily linked together: after this, therefore because of this. This is all means of causality and rational argument. In other words, we see here that the ancient Mesopotamian, in the material sequence of successive events, point out the causality,

\footnotetext{
${ }^{6}$ With a summary of, Aghababaei, $\mathrm{H}$, Religious discourse and criminalization in the field of offenses against the nation security and the state, Journal of Law and Jurisprudence, second year, Summer 2006, p. 113.
} 
that an event is related to another, then to show they were realized the similar or postulate governing alike collection, in fact, this dual awareness of the comparable and causality beyond away them of verifiable facts in the process of criminalization of behaviors. ${ }^{7}$

Accordingly, we can be observed the kind of rationality in Mesopotamia that composes basics elements consciousness in the criminalization, So that no sign of it dry and lifeless legislation cannot be found to admit some theorists in this field. Therefore the importance of refer to rational basics not what anything that we can avoid it, but also is the way that we are commended through analyze different behaviors in society, and with using such rational approach pay to the criminalization of behaviors. In fact if can be taken seriously the attitude philosophical and rational in legislative policies, in the time that can be identified general principles in the process of criminalization, and based on those principles, legislators have the ability to identify the borders and limited of the criminalization of behaviors process. Because in this way, in fact, a clear framework for legislation placed advanced the legislator that prevent of any nonconformity or inconsistency in the rules. Because before anything intellectual axes are formed for determined criminalize behaviors and the law around this axis.

However, society always has been undergone changes at the scene of modern life that in most cases, legislative policy has also caused the changes and developments. In fact explained the new patterns, basics and principles in social life style caused to that the process of criminalization of behaviors are an integral part of human life, gone through great changes, so that generally philosopher in this way had a great impacts. For example it can be noted that Cicero was trying to create a bridge among the philosopher and jurist world, and explain how can used of Greek philosophical dialogue in legal arguments. ${ }^{8}$

Therefore, the legislative nature of politics today can be derived from this attitude that if isn't overview with a philosophical attitude, Can behold the legislator in the process of criminalization on the verge of repeating the mistakes of the criminalization which seemingly simple and if you were see it with philosophical attitude, could easily prevent of them, so how the process for reaching a suitable model requires the attention of policy makers to high capacity rational and philosophical principles in fair and efficient criticism, that with used of this tools can be provide enough instruments in legislator for implement systematic legislative

\footnotetext{
${ }^{7}$ With a summary of, Botero, J, Code of Hammurabi: the concept of science and justice in the history of theory and method in ancient Mesopotamia, Translated by Hussein Badamchi, Negah Moaser Publishing, PP: 48-57

8 Westbrook, Reymond, The codex of cuneiform and being of and the legislation on rights and methodology theory, Translated by Hussein Badamchi, Negah Moaser Publishing,2015, P: 116
} 
policy. An attitude that allows to the legislature create a precise criterion for criminalize behavior.

In fact the world today is facing with many challenges in the process of criminalization that with any ways follow the domineering ways to governing dominate the political system on legislation system based on the general policy for administrating the community and its impact on a variety of legislative policy. As usually the ways that this domination political systems uses for influence and control to law-making, are as two domination policies such as direct and indirect domination policy that usually both of this features closed the way for the legislator to achieve independent legislative policy. But if you are a little more fair judgment, it seems, Will be specified the second case have more to influence and threat the will of legislator for achieve the independent legislative policy.

In fact this feature of legal systems, with liberals faces that have made in the public opinion, in the process of criminalization resort to devices such as public media, that they can with create unnecessary by the way take attention their profits in criminalizing behavior in politics.

In fact, it seems, is not possible to escape from the abyss, except with the rational and philosophical approach who can understand the hidden aspects of such a dominated system in politics and can closed the policy makers into criminalize behaviors by human manifestations, traditions, culture, values, and many other items. In other words, we cannot criminalize of behaviors based on create false demands and so in follow of advertising in public arena. In fact, the aim of such a policy is that with exploited the space that exists in society; human accepted the government through the criminalization of behaviors, then they surrounded by the power to some extent that criminalize for the legislator pattern is only homo economics ${ }^{9}$. Homo economic that their behaviors were criminalized based on profit and loss, not based on offender. In fact, the domination of politics exert policy formulation that require codification precise practice by that can be obligation and artificial rights imposes to society with using the means of criminalization of behaviors.

In fact, such rule or rules are not cause to reducing violence. But with the satisfaction of violence in the course of their policies, that influence in many aspects, including the criminalization of behaviors. ${ }^{10}$

\footnotetext{
${ }^{9}$ With a summary of Foucault, M, Bio policy, translated by Reza Najafzade, Ney publishing, 2012, p: 342

10 Foucault, Michel,"Nietzsche, Genealogy, History" In From Modernism to Postmodernism An Anthology,Blackwel Publishers,2000, pp.367-8.
} 
In fact, in this type of policy is a form of totalitarianism that by self-profit approach, its governance has penetrated into all resources and benefits of human. It should be noted that this type of policy is generally associated with Liberals chants to be able to expand its materialistic and populist pattern of legislative policy create a new crimes.

For example, with rises the slogan of supporters of women's rights in 1970, domestic violence without any legal and criminology justification, as later became clear were into crimes circle, in a manner that allows the police that attempted to arrest them without see any violence ${ }^{11}$.

In fact, rather than the act that criminal law is pay to limited to condemn the crimes inherently bad which are border agreement than of it, we observe in today's post-industrial societies are falling much more sharply criminal legal ethics, through the use of second or subsequent offenses or often just technical. ${ }^{12}$

In other words, the capacity of seeking profit policy has been moved to the side, instead of controlling the abnormal behaviors through criminalization had replacement the feature of decriminalize. In fact, the thirst utilitarianism today on major policy is extended on legislative policy. Form of politics that they weren't considered human as anthropocentric and ignored it. But some other scholars in opposite such attitudes and policies and to deal with in the dictatorial nature and capitalist thinking in liberal governments that are not considered human identity in politics, provided a perspective that could define the responsibility of man against all human.

Like currents of thought which believed, man is nothing but what it creates. Even this thought take a step further and said that every person with its choice involved everyone with the selection. ${ }^{13}$ In fact, in the process of criminalization of behavior should not lose sight of the note that every human being deserves respect not for this that the human is owned by himself but because he/ she had mind and can use his mind and so shouldn't act anything, however unimportant, that sometimes, its consequences has been involved human society, for many years let alone one that wants to with criminalize the external behavior of a rational inference harm to human values.

\footnotetext{
${ }^{11}$ Cherman, Laurence, Criminology and crime challenge and criminal sanction Science, translated by: $r$. koralivand, Judicial and Legal Justice Magazine, No. 23, Winter, 2000, pp. 77-78

$12 \mathrm{lbid}, \mathrm{P} .65$.

${ }^{13}$ Sartre, Jean-Paul, From "Existentialism" InFrom Modernism to Postmodernism An Anthology, Blackwel Publishers, 2000, p.260.
} 


\section{RATIONALIST CRIMINALIZATION AND CHALLENGES AHEAD}

What outstanding in legislative policies during the centuries is controversial interpretation of the legislative process and criminalization, that by the elimination of meaning such as justice, freedom, morality and .... marginalized its original sense, and is presented the interpretation or their meaning of those words and in criminalizing. In other words, the true interpretation of those words gradually been eradicated over time and so on with the wrong conception that of these words creates in the public mind, the legislative process has to influence today.

In the other words, when human patterns removed of such ideas justice, morality, freedom, rights and .... at the same time, which can be provide any interpretation of the ideas in legislative policy and based on that pay attention to criminalize behavior. ${ }^{14}$

In fact, in such circumstances, the legislator should not be right to own in criminalization that change concepts such as natural rights and ethics in the criminalization process. For this reason the ideas and moral values are unchangeable and unchanging in human life. Because the man was not his intention and goal it's since started moving in such a way. ${ }^{15}$

In other words, the good and evil boundaries in a society specified the values and antivalues borders for the legislator in crimination. But when these boundaries are removed, what defines can be presented as good and evil. In other words, how can in the rationalistic criminalization framework specify borders and red line in a criminalization of behaviors? Then it should be noted this point, cannot be provided interpretation of good and evil with the elimination of cultural patterns and at such a juncture that legislators in the process of criminalization is confuse that every behavior can be recognized as a crime.

In other words, the law has been lost substantive, qualitative and moral define of crime in such circumstances, and virtually don't notice to the anthropological dimension to criminalize behaviors. In fact, authoritarian and domineering spirit is coming in type and form policy to the extent that the law finds this power which in criminalization so to be surrounded on human that only the man assumes as economy factor. This means that the relationship level between the individual and the power that he applied on criminalization is based on the regulating principles the impose of power over the individual, which acts only on the basis of the economic network

14 With a summary of Riviyer, claud, Introduction on humanism, Translated by Naser Fakohi, Ney publisher, p:65

15 cs,Kant, Immanuel, "An Answer to the Question: What is Enlightenment?" In FromModernism to Postmodernism An Anthology, Blackwel Publishers, 2000, p.54. 
and as a result characterized the shape and trend of criminalization. So based on this approach, with the imagination of that we are faced with an economic man there are no difference between he violation of other traffic on the highway and intentional murder and also this will mean that from this perspective, the crime in any way, with his ethical characteristic and anthropological will not undifferentiated in politics or will not be questioned based on them. In fact, in absolute terms, anyone can be guilty, and any behavior can be recognized as crime. In other words, guilty is not anything more this on and should not be something more. So that in such circumstances the urban middle classes put into the circle the criminals without values and antivalues moral support and even social determine for behaviors that are criminalized. On the other hand, mankind in the new centuries as a legislator, than it is to look him following interpretations that he/ she reached to low level of profit. In fact, this point should not be ignored that comparing the actions and human behavior with market economy could be bring the worst form of policies within criminalize behaviors. Therefore, what is can be seen on the horizon of analysis is in no way idea or quite regular and secure community project where on the legal network is dominant on peoples via the normative mechanism and then naturally spread. Also this society no need in politics to generally normalize mechanism and remove those who cannot have failed to be the norm. Instead, in sight this approach, there are ideas or themes of a comprehensive program of legislative policy, where in there is available the space for the process without rules and instability in the criminalization of behaviors. In fact, there is bearing towards minority behaviors. In other words, act will be judged according to the rules based on pre-set rules, and not by features actors. Finally, instead of considering the humanity individuals, in the form of criminalization, is done the kind of intervention in the policymaking process. It seems we are faced with the criteria methodological framework science of law that without taking into account the principles of rational wants to criminalize behavior. In the other words, the criminalization trend of behaviors on the criminalization of rationalist should explore the nature and explanation existential conditions and the quality of acquiring it and trying to account the factors affected the criminalization of behavior. In fact, based on ontological attitude that is based on rational principles in criminalization, there is no question that policymakers and legislators to understand what it does or what must to do? But the question is in the understanding event and beyond will and act of policy maker and legislators what happens and what is logic and important factors in criminalization? In other words, legislative 
and policy makers can seek ontological approach with regard to rational principles of the criminalization not methodological. ${ }^{16}$ Because a politic cannot be create a method to uncover the truth with a methodological approach without the use of rational principles. Because if to consider this assumption, at that time this method will be equal to the rational, and such thinking essential can be dangerous for humankind and the course thinking. It seems that, in this process of what is achievable with associated of method are only a systematic and repeatable facts. Thus, according to this policy, the unrepeated and irregular facts is not a recognizable systematic. In fact, in such circumstances, at look of the legislator will stay away many factors and facts in criminalize behaviors. Perhaps for this reason that public opinion society in the light of criminalization of some behaviors, knowing some behaviors as the criminalization by legislators. In fact, with putting up the criteria as repeatable and disciplined behavior with methodological approach, it have the measure to criminalize behaviors and so in hasty form have a model for the criminalization of broad categories, insecure and generally of crime, for today's world. In other words, the legislative doctrine have achieve the voluntary dominate over the creature with using of such patterns and just practical methods without using rational basics. Until by this they can capture willingly the society with using the technology and techniques in technology ${ }^{17}$ and with purpose to earn dominance in the world people and community members have to serve their defined goals through legislative policy. In such a situation the impression is shaped in the eyes of public opinion that legislative system is a tool in the hand of government and the head of power to impose their values, as well as the suspicion arises that the law seeks to unnecessarily making value on the basis of norms of the state and sectarian. That is why it is here that the legislature system disarmed against the community's because taking adopts an irrational and unreasonable policy, and the de facto criminalization loses its their actual and potential inhibiting effect. In fact, with such a policy on criminalization provides greatly decriminalized field.

Therefore, according to this interpretation, policymakers shouldn't try to express their views only by offering policy in order to criminalize the category of behaviors. Also they shouldn't claims that the crimes world that have made with their policies, only be by category, which they have presented so that they can develop their domination rule over people's behaviors. In fact, this issue should be considered in politics, the criminalization process

\footnotetext{
${ }^{16}$ With a summary of Vaezi, A. Introduction to hermeneutics, The Islamic Culture and Thought Research Publications, 2011, pp. 217-223.

17 See for further study of ethics in the modern age, Sokhan Publisher, 2013, p. 34.
} 
understands an event that happens to us, and thus our actions or with better words; our policy isn't on audience or the behavior that is recognizing as crime, but is the act product or same behavior than us. In fact, it seems, with have a rationalist approach can be allowed to behavior provide analysis and interpretation for their criminalization to politics. Therefore, it should be pointed out that shouldn't search crime and deviations in the act person have committed, but should see through what process, the action has been legitimated must be considered illegitimate. $^{18}$

Accordingly, you should carefully consider this issue that crucial work such $t$ criminalization of behavior has always been a framework with which the base of this takes shape law. If that's the beginning, middle, and end with a set of factors, that policies adopt in the minds of policymakers with think to human society. In fact in this stage legislator with passing of thinking stage has to find a pattern in criminalizing his thought arrives to certainty in criminalizing of certain behavior. ${ }^{19}$

Therefore with considering above interpretations can be said that the various policies form with take impact from the ideas of each other. So that base on casual system impact on each other as continuing consequence, until will achieve category of behaviors. Also the criminalization trend can be independent identity when involved with the practical aspects in the legislative process. In fact, the law is likely to occur under conditions that can be determined in the process, different aspects of values and anti-values for the criminalization of behavior. In the other hand, the identity of an independent policy depend that policy when and how will lead policymakers and legislators to the criminalization of behavior. Accordingly in this way can be understood that in the implementation of a policy of criminalization of behaviors legislation, runtime and how to implement it is important as a rule to what extent. Therefore, with such logic in the process of criminalization legislator allow to reconsider own vision, and instead of, in the process of criminalization only consider its concrete aspects, the law becomes character that always evaluates himself with the conscious knowledge. As one of the results to evaluate

\footnotetext{
${ }^{18}$ With a summary of Habbibzadeh, M. Zeynali. An introduction to some practical limits of criminalization, Name Mofid, legal, Volume 1, Number 1, 2006, p. 13.

19 Peirce, Charles, From "How to Make Our Ideas Clear" In From Modernism to Postmodernism An Anthology, Blackwel Publishers, 2000 pp.145-8.
} 
the process of criminalization of behaviors will be self-awareness of legislator about the strengths and weaknesses of theoretical and practical criminalization. ${ }^{20}$

In fact, with this rational approach will not be to other field's legislation only reference to the usual and ordinary crime, but other aspects will emerge in the criminalization of behaviors process. In other words, on the basis of such a model should look for this subject those rational aspects in the criminalization to replace a part of its experimental aspects, and accordingly self- awareness are presented to intellectual core which are formed based on, so that this way can, legislative policy closed to absorption of rationalist architecture with using such a model philosophical teachings in criminalizing acts. In fact, we're in the system following the criminalization of the behavior finds these possible that in the self- manage system with using of rational basics, repair themselves and revised their strengths and weaknesses. In other words, when reason and rationality is governing in legislation the strengths and weaknesses criminalization of behaviors is evident for legislators because at that time, the philosophical approach will have profit to criminalization.

\section{THE LIMITS AND BORDERS OF RATIONALIST CRIMINALIZATION}

The law always takes shape on the framework of general principles that according to which, the details are established accurately and recognized the limits and borders and legal framework. In fact, that's why the legislation or in other words, the process of legislation is followed as a framework that aims ideas, principles, principles, ideas and methods to be determined in the form of a law. fact, if the aims, ideas, principles, basics, ideas and methods put in rational framework or to better express to be assessed the rationality criteria, it can be determined the limits and borders of criminalization on the specific framework. In other words, determine the limits and borders of criminalization process within the rational framework legislative, legislative system had far from many deficiencies and somewhat close us to rationalist criminalization borders. Therefore, on this basis, believe that with careful observation in the subject ahead close to aspects of the limits and borders of criminalization of rationalist approach. One of these aspects, is transferring legislative law basics and principles to substantive law and use of it for the criminalize behaviors. In fact, on the basis of such an

\footnotetext{
${ }^{20}$ CS,Habermas, jürgen," An Alternative Way out of The Philosopershy of The subject: Communicative versus Subject-Centered Reason" In From Modernism to PostmodernismAn Anthology, Blackwel Publishers,2000, pp.591-2.
} 
attitude and thought can be take an account the tradition as the main source of moral basics and social rules in the legislative law. Accordingly, the law and rule has been created of the depth public conscience and the average ration of people and by the unclear stream that transfer to substantive law for criminalization. ${ }^{21}$

In other words, the general legal principles will be a rational difficult task, which is usually transmitted increasingly through legal procedure to substantive law. If legal precedent isn't inspired by the legislative law, it can be away from many of the realities of criminalization. In fact the process of criminalization cannot exceed of the nous of average people because it is a rational system. ${ }^{22}$

So customary or legislative rights should not be considered equivalent to repeat certain actions, but it is the replication of external means to announce and expression. As a result, accepted the concept of legal certainty in policies and criminalization is the basic that custom principle of the practice placed on it. In fact, the tradition as a source of legislative law in the meantime is represents of collective certainty in relation to a particular matter, with no doubt usually acquires their source of individual conscience, then in such situations, the legislator can be faced with two issues to criminalize behaviors; 1 - The legislative law, 2-Substantive law.

In fact the communication can exist in convey the concepts of legislative law to substantive law save the criminalization of many shortcomings in legal cases and creates unity on it. In fact, in the legislative law can be followed for a system of legal rules for criminalization that could create actual news and discipline in the life of a nation on certain period of history as well as in substantive law can be find legal rules that really could have find peremptory power and practically find the executive branch. So it can be said on the same basis; conveying custom concepts of legislative law to substantive law can be save the law of many shortcomings in achieved the comprehensive in regulation. Of course whether the process to be done properly as conveying custom concepts of legislative law to substantive law or the same process of criminalization of behaviors. In fact, at such a time that can be current policies legislation to criminalize behavior has the moral basis of the society for this perspective which they has been get accepted values.

Other orientation to achieve the limits and border of behaviors criminalization is using a pragmatic policy to criminalize behaviors. Pragmatic policy, which means that by the political

\footnotetext{
${ }^{21}$ With a summary of Delvokio, J, philosophy of law, translations by Javad Vahedi, publishing of Mizan, 2007, p. 83.

22 Westbrook, Reymond, The codex of cuneiform and being of and the legislation on rights and methodology theory, Translated by Hussein Badamchi, Negah Moaser Publishing, 2015,P: 91
} 
theory are derived from the social and norms values and principles with regard to cultural community, established the basis for pragmatic policy. In fact if we couldn't planning the pragmatic policy in accordance with the principles of normative political theory, social, cultural, religious and national community achieve to pragmatic policy would be impossible to criminalize behaviors. Because at this time often abstract mental regardless of attention to realities and historical facts and philosophical of norms community basis for the policy theoretical, that in such policies do not correspond to the norms and values of its society. In fact, in such circumstances received to the pragmatist policy and use it to criminalize behaviors seems so far-fetched.

Another step to determine the limits and borders of rationalist criminalization have a unity and coherent legislative policy to criminalize behavior. So that the legislator is criminalize behaviors on the basis of a single legislative policy. Until legislators can integrated behaviors that are known as crime so that each section of behaviors that are criminalized, they complement the other part. In fact, in this way, each part can cover the weaknesses of other part. In fact, according to the legislator's approach uses an integrated line of thought in criminalizing behavior. In other words, for example, cannot be advanced part of the criminalization of pure legislative policy Marxist and in another part advanced with utilitarian approach. As these two concepts are exorcise the effect of each other for criminalization.

In fact, it seems, lines of thought on the politics that are subscriptions put as basis of criminalize behaviors if the legislator to it, so advanced that Subscription or in other words, points or Subscription trajectory put the basis of the behaviors criminalization ${ }^{23}$, the best solution is to criminalize behaviors. Because organized legislative policy will be sometimes result of two heterogeneous policies for criminalization. The effects of legislative policy on its face have purpose to use to the conflict in the various policy criminalize and instead of neglecting them towards shaping the policies that are immune to paradox, benefit from them.

On the other hand, maintain the moral core in the law is as unchanging basis that can identify common borders ethics and law. Principal isn't change at any time and place. In other words, in the criminalization of behaviors can be maintained moral absolutist framework that it prevents of any influence relativism on the legislative.

\footnotetext{
23 cs,Habermas, jürgen," An Alternative Way out of The Philosopershy of The subject: Communicative versus Subject-Centered Reason" In From Modernism to PostmodernismAn Anthology, Blackwel Publishers,2000,p.611.
} 
However, on the other hand, in opposite of such logical, we see this trend of subject that moral relativism policy surrounded the criminalization trend in today's world and practically the law devoid of ethics and fundamental principles as far as even think legislation to moral matters in today's world are invective by many citizens of modern societies, because in their view raises despotism. ${ }^{24}$

The starting point for such thinking must be searched at the beginning of the 70s decade as proposed in the domain of crime was raised by criminologists.

This attitude is summed up in two principles: 1- Immorality, therefore is not sufficient to criminalize an act 2- This principle that isn't new in itself period by people like Mr. Hall's in "The relationship between the crime with social progress" book solemnly announced, the depths of obscenity and ugliness moral in itself is not sufficient to criminalize. On the other hand, Neural Morris commented that the criminal law should not be used to avoid people of sin, including those guilt and the sins that harm only the guilty. Should not be used criminal law to avoid going to hell. It is argued that, an action shouldn't be made a crime just because some people or most people imagine it nasty, inappropriate and disgusting. Because in a democratic and free society cannot be imagined, the law announced a treatment criminal as it is believed by some reprehensible behavior, unnatural or abnormal. Unless it is clearly proved that behavior is socially harmful or damage to the rights of others. ${ }^{25}$

In fact with argued about such views which over many meanings of terms was reminisce such as rights and freedoms of other meanings replaced by other meanings. In fact, the right, freedom or choice in their communities was replace rather than real meaning in people's minds, and returned only to satisfy the demands of the people that they are not chosen it practically. For this reason, with the use of terms such democratic and freedom communities identified behaviors as crime that was providing some interests. In other words, the views of those involved in the process of criminalization of behaviors were not absolute intrinsic value of human, but take account the relative value. ${ }^{26}$

With this aim the human is not the purpose of legislator to anthropocentric human as the existing that has nous, and in criminalizing behavior to be treated that is tools not target so

\footnotetext{
${ }^{24}$ With a summary of Sandell, M, Justice: What's the Right Thing to Do?, translated by Hossein Afshar, 2015, p. 21

25 Abdolfatah, E. What is crime and what is the criminal criteria, translated by Esmail Rahiminezhad, Justice legal magazine, Issue 41, 2002, pp.155-156

${ }^{26}$ With a summary of Sandell, M, Justice: What's the Right Thing to Do?, translated by Hossein Afshar, 2015, p. 121
} 
they considered the human dignity. So with a glance to this background in in the legislative process in today's world, it seems in criminalization preserving human dignity that is owner of nous or the human that carrying humanity, whatever the default is something that remains unknown and neglected as far as the respect basis to rational argument for all human beings in the legislative is that case have been forgotten. Therefor with this descriptions on the convert such logic, in here maybe in legislation specified relative of ethics and freedom. Because the moral act means act based on responsibly for the moral law is an absolute and original task, who wants us to respect everyone as an end in it, and even freely know the criminalization of behavior when that is in accordance with the absolute task. Because whenever in accordance Contingent on would be paid to the criminalization of behaviors, for profit and goal that is determined out of the legislative process, and it will be outside of the humanity nature. ${ }^{27}$

So at this time, we haven't a law where consider to freedom. Because the human's will don't determine with such logic as I as human in the legislation. But other force out of me as human will determine necessity, conditions, demands and needs. For this reason, it seems, nous and freedom is falling apart in the process of criminalization of behaviors.

So legislator, in the worst states should also try to at least maintain the core morality on the type and form of its criminalization. Because when people like Wittgenstein believe to moral relativism believe in criminalizing, murder put on the same level as that of any other event occurs such as a falling stone ${ }^{28}$, such a view cannot be hoped with the order and security of society through legislation in the domain of criminal law. In fact, we can somehow have hoped to order and security by the legislation when in a step forward in the domain of crime, the obligation of this being in its mine. In other words, the legislators should be looking policies in the legislature that through the values and anti-values has been flow in the society with respect of historic past until today realized to its original meaning with the limits and borders of criminalization of behaviors in tradition and the obligation from within comply in the law at the sight of people's community. In other words, what we are witnessing today in policy making is the use of surface thoughts in criminalizing behaviors by theorists and policy makers which can only create, at best status, the obligation of outside for follow or avoid some behavior in public opinion.

\footnotetext{
27 Ibid., P. 123.

28 Wittgenstein, Ludwig, "Lecture on Ethics" From Tractatus Logico-Philosophicus In From Modernism to Postmodernism An Anthology, Blackwel Publishers, 2000, p.19.
} 
In fact, they only had material appearance and face of human as measure for its policies. Therefore, to avoid such a model should be acted as by criminalizing of behaviors is contained its own of do or don't an action and abnormal behavior which of legal view recognized as crim. In fact, the legislator by this way compels people to obey the law that were taken of respectfully values of them. However, despite such an interpretation of the legislation can be taking a profit of deep philosophical theory also in this way. Mulla Sadra believes in the substantial motion theory as a matter of human such his mood and behavior is moving, his essence is moving also as its ego. According to the words of the "Mulla Sadra" essence of man is moving that affect human material. In fact, his opinion focused on this issue that cannot be accepted the human is moving but his essence isn't moving such as childhood, adolescence, youth to old age. ${ }^{29}$ In fact from him consider, substantial motion, or with other word, this process is a circumstance that is in all he entire universes. In other words, by changing and moving in the human soul that man's belief is experiencing transformation or his action, which is derived from his faith, appears his behavior. In fact, his faiths are his action or to better express his behavior. Accordingly, if the legislator can be properly analyzing man's appearance that's behavior and moral traits, with no doubt can be in criminalization, in addition to the obligation of the outside, creates obligation of inside on peoples. Therefore, if the soul, to be considered, correlation and coordination between the soul and substance of human will be exists according to substantial motion theory that changes in physical traits of humans actually are emanating from his soul. In fact the matter and soul of human can, too, are affected and influence. So as by use such view in legislative policy as in the criminalization can be brought the obligation of outside as well as obligation of inside. In fact, it seems, challenge is facing the legislator today's in legislative is lack of right and shrewdly view by him even in moral traits analyze, human behavior in criminal behavior that in material appearance is expressed that cannot create obligation outside and then subsequently of inside with the criminalization of behavior in human today. In other words, if the legislator in the diagnosis of human appearance traits has function probably for control his behavior through the criminalization of behaviors, without a doubt could involve human soul in compliance with the law.

\footnotetext{
${ }^{29}$ With a summary of Shokry, M. Kord Firozjani, y. Analyzing and survey the materiality of the soul of Mulla Sadra's view, The Journal of religious study of human, The ninth year, Fall and winter 20013-20014, pp: 101-102
} 


\section{CONCLUSION}

Rationalist criminalization can be characterized with using of philosophical foundations that perhaps of experts views and teachings of other disciplines becomes less attention such as criminal law is far-fetched. In fact, this approach in criminalize behaviors can be so significant that can down the rate of errors in the process of criminalization For example, if the legislator don't criminalized behaviors in time and the right place that by the legislator of beginning the work, In the time that we can hope to have this behavior that is criminalized by legislators is also provided in the eyes of public opinion and the subsequent obligation of outside and inside. But if the same act or behavior does not occur in their proper time and place when not only it will not create obligation of inside but also have to waiting much worse consequences of such an act. ${ }^{30}$ Therefor use of rational principles, as is quite tangible, from the legislator can seem so simple that is not at the same sensitive level in his/her opinion to criminalize behaviors. In fact, with regard to the interpretation of the above, the legislator in today's world more than what are looking as Wisdom with followed condition which lives in or imposed on him, immersed in experiences, or think that applies him / her nous in legislation. In other words, the definition of nous and rationality in today's world have transformed and more moved in materialistic ideas and techniques in technology. In fact, today's the legislator has forgotten many of rationalistic patterns in criminalizing behavior that by thinkers and philosophers such as Aristotle, who have been consider forth and continued dignity of theoretical intellect, practical wisdom, ethics and for human. ${ }^{31}$ A pattern if haven't result except act and or act the imagination of nous and rationality seemed impossible for the act or behavior. In fact, for example in the use of multiple theories, if someone in criminalizing behavior such the legislator claims who has used of his intellect, it's behavior must consistence with moral patterns that criminalizing by him and that's results are nothing another things except support of ethical norms. For if such an act that is criminalized is the other result by legislator would not be rational and based on quote of Aristotle will not result to the origin of the good.

However, today in the process of criminalization of behaviors are faced with the ideas in the realm of legislation that easily can be misrepresentation and the invalid subject convert to right and right seem wrong. In other words, with a glaze to post-modern ideas that the margins

\footnotetext{
${ }^{30}$ With a summary of Davari Ardakani, R. Moral in Modren ages, Sukhan Publisher, 2013, p: 32

${ }^{31}$ Ibid
} 
that make text, ${ }^{32}$ it must be said that today the scene of the legislative margins that are in the text once in the criminalization of behaviors, today in a way that might not be believable even to the legislator's effectively marginalized And no choice but to use the other topics in criminal law, such as philosophical insights will adopted rational principles of it and we apply in the process of criminalization, so that such filtering could prevent it from entering non-rational foundations. In fact, we need to understand that rights are just a fan, not a string, it wants without the use of scientific principles in other disciplines, such as philosophy achieve comprehensive results in the criminalization of behaviors.

\section{REFERENCES}

Abdolfatah, E. What is crime and what is the criminal criterion, translated by Esmail Rahiminezhad, Justice legal magazine, Issue 41, 2002

Aghababaei, $H$, Religious discourse and criminalization in the field of offenses against the nation security and the state, Journal of Law and Jurisprudence, second year, summer 2006

Botero, J, Code of Hammurabi: the concept of science and justice in the history of theory and method in ancient Mesopotamia, Translated by Hussein Badamchi, Negah Moaser Publishing

Badamchi, Historical sociology of criminal law, Negahe Moaser Publishing, 2005, Cherman, Laurence, Criminology and crime challenge and criminal sanction Science, translated by: $r$. koralivand, Judicial and Legal Justice Magazine, No. 23, Winter, 2000

Davari Ardakani, R. Moral in Modren ages, Sukhan Publisher, 2013

Delvokio, J, philosophy of law, translations by Javad Vahedi, publishing of Mizan, 2007

Farajiha, M, Aspects of affected criminology on criminal policy, Modares Law Journal, Volume 7, No. 1, Spring 2004

32 cs, Cahoone, Lawrence, From Modernism to Postmodernism An Anthology, Blackwel Publishers, 2000, p.16. 
Foucault, M, Bio policy, translated by Reza Najafzade, Ney publishing, 2012

Foucault, Michel,"Nietzsche, Genealogy, History" In From Modernism to Postmodernism An Anthology,Blackwel Publishers,2000

Habbibzadeh, M. Zeynali. An introduction to some practical limits of criminalization, Name Mofid, legal, Volume 1, Number 1, 2006

Iranpur, Farhad, Rethinking on legal methodology and epistemology, Rokhdadeno publisher, 2013

Marti, D. Huge systems of criminal policy, Translated by Ali Hossien Najafi Abrand Abadi, Mizan, Volume of 2, 2008

Sandell, M, Justice: What's the Right Thing to Do?, translated by Hossein Afshar, 2015, p. 21

Shokry, M. Kord Firozjani, y. Analyzing and survey the materiality of the soul of Mulla Sadra's view, The Journal of religious study of human, The ninth year, Fall and winter 20013-20014

Vaezi, A. Introduction to hermeneutics, The Islamic Culture and Thought Research Publications, 2011

Westbrook, Reymond, The codex of cuneiform and being of and the legislation on rights and methodology theory, Translated by Hussein Badamchi, Negah Moaser Publishing, 2015

Riviyer, claud, Introduction on humanism, Translated by Naser Fakohi, Ney publisher

Trabalho enviado em 17 de fevereiro de 2018.

Aceito em 07 de março de 2018. 